\title{
Kitlesel Açık Çevrimiçi Ders Yoluyla Yabancı Dil Olarak Türkçe Öğrenenlerin Profili*
}

\author{
Özlem Ozan ${ }^{* * 1}$ ve Yasin Özarslan ${ }^{2}$
}

$\ddot{O} z$

Anahtar Sözcükler

Bu çalışmada Türkçe Öğreniyorum kitlesel açık çevrimiçi dersine (Massive Open Online Course: MOOC) kayıtlı yabancı dil olarak Türkçe öğrenmek isteyen 104 ülkeden ve 136 milliyetten 6254 öğrenenin; Türkçe öğrenme nedenleri, anadilleri, milliyetleri ve yaşadıkları ülkeler, eğitim seviyeleri, çalışma durumları, bildikleri yabancı diller, internet kullanım alışkanlıkları ve ilgi alanlarına dair dağılımların ve bunlar aralarındaki ilişkinin incelenmesi amaçlanmıştır. Yabancılara Türkçe öğretimi alanyazınında hem yurtiçindeki ve yurtdışındaki yabancıları hem de böyle büyük ve çeşitlilik arz eden bir örneklemi kapsayan başka bir yayın henüz yer almamaktadır. Bu nedenle çalışma, Türkçe öğrenmek isteyen yabancıların demografik özelliklerini ortaya koyarak genel bir bakıș açısı sunması ve program geliştiricilere politika oluşturma süreçlerinde yol gösterici bilgi sağlaması bakımından önemlidir. Araştırmada, kesitsel tarama modeli kullanılmıştır. Veriler, öğrenme yönetim sistemi için özelleştirilen Kayıt Formu üzerinden toplanmıştır. Analiz sonuçlarına göre yabancı dil öğrenmek isteyenlerin çoğunluğu Türkiye'de yaşamaktadır $(n=4158, \%$ 66.49). Yarıdan fazlası ikinci bir dil deneyimine sahip değildir $(n=3796, \%$ 60.70). Büyük çoğunluğunun anadili Arapçadır $(n=5100, \% 81.55)$. Yarıya yakını önlisans veya lisans eğitim seviyesine sahiptir $(n=2782, \% 44.48)$, yine yarıya yakını çalışmaktadır $(n=$ $2769, \%$ 44.28). Öğrenenlerin yaklaşık dörtte üçünün çevrimiçi bir ders deneyimi bulunmadığ ${ }_{1}(n=4617$, \% 73.82)ve yarıdan fazlasının ( $n=4253, \%$ 68.00) sosyal ağları kullandığı belirlenmiștir.

$$
\begin{array}{r}
\text { Kitlesel açık çevrimiçi } \\
\text { ders } \\
\text { Açık ve uzaktan } \\
\text { öğrenme } \\
\text { Yabancı dil olarak } \\
\text { Türkçe } \\
\text { Öğrenen profili } \\
\text { KAÇD } \\
\text { Makale Hakkında } \\
\text { Gönderim Tarihi } \\
\text { 16 Ekim 2018 } \\
\text { Kabul Tarihi } \\
\text { 01 Aralık 2019 } \\
\text { Makale Türü } \\
\text { Araştırma Makalesi }
\end{array}
$$

\section{Profile of Turkish Learners as a Foreign Language via a Massive Open Online Course*}

\section{Abstract}

In this study, profile analysis of 6254 learners, who were from 104 countries and 136 nationalities, registered in Türkçe Ögreniyorum (Learn Turkish) MOOC, was performed. The aim of this study was to examine the distribution of Turkish learning reasons, mother tongue, nationality and country of residence, education level, working status, number of foreign languages spoken, internet usage habits and interests of learners in addition to the relationship among these parameters. This is the first study, which includes such a large and diverse sample, in the study field of teaching Turkish as a foreign language. Therefore, the study is important since it might provide an insight into learner demographics to program developers in policy-making processes. In this research, cross-sectional survey design was used. Data were collected through the Registration Form integrated into the learning management system. According to the results, most of the users, who wanted to learn Turkish as a Foreign Language, lived in Turkey $(n=4158,66.49$ $\%)$. More than half of the learners did not have a second language $(n=3796,60.70 \%)$. The native language of the majority of the sample was Arabic $(n=5100,81.55 \%)$. Nearly half of the participants had an associate or bachelors' degree $(n=2782,44.48 \%)$, and approximately half of the participants were working $(n=2769, \%$ 44.28). Approximately three-quarters of the learners had not had an online course experience $(n=4617,73.82 \%)$ and more than half indicated $(n=4253, \% 68.00)$ using social networks.
Keywords

Massive open online course

Open and distance learning

Turkish as a foreign language

Learner profile MOOC

Article Info

Received

October 16, 2018 Accepted

December 01, 2019

Article Type

Research Paper

Atıf: Ozan, Ö. ve Özarslan, Y. (2019). Kitlesel açık çevrimiçi ders yoluyla yabancı dil olarak Türkçe öğrenenlerin profili. Ege Eğitim Dergisi, 20(2), 366-382. doi: 10.12984/egeefd.471057

\footnotetext{
* Bu çalışma, 115K270 proje kodu ile TÜBITTAK’’n desteklediği Türkçenin Yabancı Dil Olarak Farklllaştırlmış Uzaktan Öğretimi projesi kapsamında araştırmacıların geliştirdiği Türkçe Öğreniyorum Kitlesel Açık Çevrimiçi Dersi verilerinden hazırlanmıştır. [The data in this study has been acquired from Türkçe Ögreniyorum (Learn Turkish) Massive Open Online Course which is developed by researchers under Differentiated Distance Education of Turkish As Foreign Language Project and supported by TÜBITTAK with the project code of 115K270.] Sorumlu Yazar/Corresponding Author

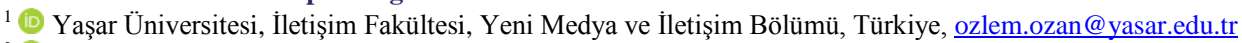

2 (ㄷ) Yaşar Üniversitesi, İletişim Fakültesi, Yeni Medya ve İletişim Bölümü, Türkiye, yasin.ozarslan@ yasar.edu.tr
} 


\section{Extended Abstract}

\section{Introduction}

Teaching Turkish as a foreign language emerged as a field especially after 2000s. The governmental institutions that teach Turkish as a foreign language are TÖMER (Turkish Education Centers) and Yunus Emre Foundation, both in Turkey and abroad. Turkish Education Centers teach Turkish language face-to-face within the universities, whereas Yunus Emre Foundation conducts distance education in addition to face-to-face education. However, these institutions do not have any initiatives for massive open online courses for people seeking alternative ways to learn Turkish.

Massive Open Online Language Courses (MOOLCs) is a recent educational phenomenon of online learning that can promote language learning. According to 2017 report of Class Central, which is a massive open online course search engine, there are over 7000 of MOOCs across the world. 155 of them are MOOLCs. For example, Coursera platform provides 129 MOOLCs whereas Edx platform provides 27, and Future Learn platform provides 6. Only the Udemy platform provides a MOOLC for learning Turkish as a foreign language. However, it is not delivered by a university. Currently, Türkçe Ögreniyorum (Learn Turkish) is the only academicoriginated MOOLC running properly. It is delivered by Yasar University via https://turkish.yasar.edu.tr/. Türkçe $\ddot{O}$ greniyorum platform is a MOOLC specific to teaching Turkish as a foreign language. It was developed under a research umbrella as the product of Differentiated Distance Education of Turkish as a Foreign Language project, supported by TÜBİTAK with the project code of $115 \mathrm{~K} 270$. It is limited to level A1, which is referenced in the Common European Framework of Reference for Languages. A wide variety of qualified content (as videos, audios, readings, and games) is provided to learners in this platform.

In this study, the profile analysis of 6254 learners who were registered in Türkçe Öğreniyorum platform was performed. The aim of this study is to examine the distribution of Turkish learning reasons, mother tongue, nationality and country of residence, education level, working status, number of foreign languages spoken, internet usage habits, and interests of learners in addition to the relationship among these parameters. Current empirical research into the demographics of non-native Turkish learners is still scarce. In these studies, the sample is homogeneous and has low diversity. In addition, the sample size is small (Aktaş and Uzuner Yurt, 2015; Biçer, 2017; Bozkurt and Uzun, 2015; Büyükikiz, 2014; Dönmez and Gündoğdu, 2016, Erdem, Gun, Sengul and Ozkan, 2015). There is no other study in the literature on teaching Turkish as a foreign language, which covers such a large and diverse sample including informal foreigners both in Turkey and abroad in addition to people who are out of formal education. Therefore, this study would contribute to decision-making processes by providing qualified and comprehensive data to field practitioners and policymakers. Rectorate of Yaşar University announced Türkçe Öğreniyorum MOOC to the Ministry of National Education, Ministry of Foreign Affairs, Ambassadors, Yunus Emre Institute, and the Presidency for Turks Abroad and Related Communities $(Y T B)$. The enrolment rates increased to six thousand after the announcement. We reached the targeted audience since the system was announced through official channels and there was institutional support behind it. Hence, participants of this study are representative of the population who want to learn Turkish and do not have problems in accessing information and communication technologies.

\section{Method}

In this research, cross-sectional survey design was used. The participants of the study are 6254 learners, who voluntarily registered to the system between the dates of 30 June 2017 - 30 June 2018, from 104 different countries and 136 different nationalities. The data were collected using a registration form that was customized for the learning management system and presented in English, Arabic, Russian, and French. Descriptive statistical methods were conducted to analyze the data. In addition, analyses were performed to examine whether there were statistically significant differences between variables. The effect size was measured using Cramer's $V$ (Özsoy \& Özsoy, 2013). In the analysis of the data, Bonferroni correction was performed. $31.68 \%(n=1981)$ of the participants were female and $65.80 \%(n=4115)$ of them were male. $2.53 \%(n=158)$ of them did not prefer to declare their gender. $4.35 \%(n=272)$ of the participants were under 18 years old, $26.16 \%(n=1636)$ of the participants were between 18-24 years old, $40.87 \%(n=2556)$ between 25-34 years old, $19.04 \%(n=1191)$ between $35-44$ years old and $9.57 \%(n=599)$ of the participants were above 45 years old.

\section{Findings}

According to results, $62.77 \%(n=3926)$ of learners want to learn Turkish for general purposes such as personal interest, travel, cultural curiosity, and having Turkish speaking relatives, friends, neighbors. 54.28\% $(n=3395)$ of them declared that they have academic purposes and rest of them $(44.42 \%, n=2778)$ stated their aim as 
business. The mother tongue of $81.55 \%(n=5100)$ of learners was Arabic. Arabic is followed by English $(2.94$ $\%, n=184)$ and Persian $(1.58 \%, n=99)$ respectively. Half of the learners $(50.98 \%, n=3188)$ were Syrian. However, only $133(2.13 \%)$ of them stated that they were living in Syria. The majority of registered learners $(66.49 \%, n=4148)$ resided in Turkey. $10.92 \%(n=683)$ of the learners have primary or secondary education, $31.90 \%(n=1933)$ of them have a high school or equivalent degree, $44.48 \%(n=2782)$ of them have associate or bachelor's degree, $11.12 \%(n=696)$ of them have a master's degree and $2.56 \%(n=160)$ have Ph.D. degree. A chi-square test of independence was performed to examine the relation between residency and education level. The relation between these variables was significant, $(\chi 2(3)=237.104, p<.001$, Cramer's $V=.20) .44 .27 \%(n$ $=2769)$ of learners were employed. $15.31 \%(n=958)$ of them stated that they were not working. $28.53 \%(n=$ $1784)$ of them are students. $60.70 \%(n=3796)$ of the learners did not know any other foreign language. $32.08 \%$ $(n=2006)$ spoke one foreign language. $73.82 \%(n=2769)$ of them had not had an online course experience. $68.00 \%(n=4253)$ of them indicated using social media. Men are more interested in Business, Developments in the World, Science, Technology, and Sports than women while women were more interested in Fun and Life, Language and Culture, and Literature.

\section{Discussion and Conclusion}

Teaching Turkish to foreign people in Turkey mainly takes place in universities. Turkish Education Centers (TÖMER) are the pioneers in this field. The coordination of this issue is done by the Yunus Emre Institution in abroad. However, it is difficult to meet the demands toward learning Turkish all over the world trough face to face education and to reach every individual who wants to learn Turkish in this way. At this point open and distance learning emerges as an alternative solution. There are two traditional distance education programs to teach Turkish as a foreign language, and only one comprehensive, well-structured, non-profit MOOLC. Distance education programs are provided by Anadolu University and Yunus Emre Institute, where the MOOLC is provided by Yasar University under the course titled of Türkçe Ögreniyorum. In this study, profile analysis of 6254 learners registered in Türkçe Ögreniyorum was presented. This is the first study, which includes such a large and diverse sample in the study filed of teaching Turkish as a foreign language. Therefore, it might provide an insight into learner demographics for program developers in policy-making processes. 


\section{Giriş}

Türkçenin yabancı dil olarak öğretimi son yıllarda hem yurt dışında hem de yurt içinde ilgi gören ve daha fazla çalışılan akademik bir alan haline gelmiştir (Ozan ve Göçmenler, 2018). Yurt içinde yükseköğretim düzeyinde yabancılara Türkçe öğretimi TÖMER (Türkçe Öğretim Merkezi) aracılığı ile yürütülmektedir. Yurt dışında ise yabancilara Türkçe öğretiminin; Yunus Emre Enstitüsünün diğer ülkelerdeki merkezleri, Türkoloji bölümleri ve doğu dilleri çalışan fakültelerce yürütüldüğü görülmektedir. Türkçenin yabancı dil olarak öğretimi yaygın olarak yüz yüze yöntemlerle gerçekleştirilmektedir. Ancak artan talebin sadece yüz yüze yöntemler ile karşılanması pek mümkün gözükmemektedir. Yunus Emre Enstitüsünün 2016 faaliyet raporu dışında yurt dışında yaşayanların Türkçe öğrenme taleplerine dair yakın zamanlı bir istatistik ile karşılaşılmamakla birlikte (Yunus Emre Enstitüsü, 2016) söz konusu rapora göre Yunus Emre Enstitüsü bünyesinde 12000 öğrenci Türkçe öğrenmek için kurslara kayıtlanmış, seçmeli olarak alınan Türkçe dersleri ile yabancı dil olarak Türkçe öğrenenlerin sayısı 20000'e ulaşmıştır. Öte yandan karşılanamayan talepler ile ilgili herhangi bir veri paylaşılmamıştır. Yükseköğretim Kurulu Başkanlığı (2018) verilerine göre 2016-2017 eğitim öğretim yılında toplam 108076 yabancı öğrenci Türkiye'de eğitim görürken bu sayı 2017-2018 eğitim-öğretim yılında 125030'a yükselmiştir. Diğer taraftan Millî Eğitim Bakanlığı bünyesinde Türkiye'de öğrenim gören yabancı uyruklu öğrencilerin sayısı, 2016-2017 eğitim-öğretim yılında toplam 232714'tür [İçişleri Bakanlığı Göç İdaresi Genel Müdürlüğü (İBGİGM) Göç raporu, 2016]. Göç idaresi verilerine göre ise ikamet izni ile Türkiye’de bulunan yabancıları sayısı 02.08.2018 tarihi itibarıyla 718297'dir (İBGIGM, 2018). Türkçe öğrenmeye gereksinim duyan bu çaptaki kitlenin ihtiyaçlarının sadece yüz yüze eğitimlerle karşılanması zordur. Gelişen teknoloji ile beraber zenginleştirilmiş materyallerin öğretim sürecine dahil edilmesi giderek öğrenimi daha işlevsel hale getirmektedir (Nicoll, MacRury, van Woerden ve Smyth, 2018; Kirkwood ve Price 2011, Liu, Moore, Graham ve Lee, 2002). Bu konuda Yunus Emre Enstitüsü'nün zenginleştirilmiş kitap ve Anadolu Üniversitesi'nin uzaktan eğitim yoluyla Türkçenin öğretimine yönelik yaptığı çalışmalar alan açısından önemli faaliyetler olmuştur.

Günümüzde teknolojinin eğitim sürecinde artan bir ivme ile daha yaygın ve entegre olarak kullanılması dil öğrenen genç kuşağın da tercihleri arasında ifade edilmektedir (May ve Thorne, 2017). Diğer taraftan halihazırda birçok bireyin yurt dışında ve içinde Türkçe öğrenmek için talepte bulunması ve bu talebin karşılanamaması, her bireye ulaşılması konusunda işlevsel çözümlerin bulunmasını gerekli kılmaktadır (Ozan ve Göçmenler, 2018). Özellikle dünyada gelişen teknolojiyle öğretim imkânlarına tam olarak ulaşamayan bireyler açısından uzaktan eğitim çözümleri yaygın biçimde kullanılmaktadır. Bireylerin kendi hızlarında öğrenebildikleri, öğrenme biçimlerinin dikkate alındığı açık ve uzaktan eğitim uygulamaları olarak Kitlesel Açık Çevrimiçi Dersler (KAÇD; Ingilizce: Massive Open Online Course-MOOC) yüz yüze eğitimin götürülemediği durumlarda alternatif bir çözümdür. Temel niteliği itibarı ile bireysel çalışmaya yönelik olan KAÇD’ler, geleneksel uzaktan eğitim ortamlarından kayıtlanan öğrenci sayısı, erişilebilirlik, açıklık ve etkileşim gibi boyutları ile farklılık göstermektedir. Geleneksel uzaktan eğitim ortamlarında bir sınıftaki ideal öğrenci sayısı tıpkı yüz yüze eğitimde olduğu gibi 20-24'tür (Moore ve Kearsley, 2005). KAÇD’ler de ise böyle bir sınıf yapısı yoktur. Kitlesellik kavramı, bir derste aynı anda 1000 ila 100 bin gibi çok sayıda öğrenciye işleyiş açısından sorunsuz erişim sağlamayı ifade etmektedir. Açıklık kavramı; derse kayıtlanma için bir ön koşulun olmaması ve içeriğin açık erişimle ücretsiz olarak sunulmasına gönderme yapmaktadır. Okuma-yazma bilen ve temel bilgisayar becerilerine sahip herkes bu derslere kaydolabilir. Çevrimiçi kavramı ise derslerin fiziksel olarak bir araya gelmeden uzaktan yürütülmesi bağlamında kullanılmaktadır (Perifanou, 2016; Ozan, Ozarslan ve Yildiz, 2018). KAÇD’lerde esnekliğin yüksek olması ve öğrenenin öğrenme sürecini zaman-mekân-hız bakımından istediği gibi yapılandırabilmesine rağmen öğretmen-öğrenci, öğrenci-öğrenci etkileşimi düşüktür. Öte yandan KAÇD’ler, öğrenme materyali sunan web siteleri gibi de düşünülmemelidir. İçeriklerin bir müfredat dahilinde yapılandırması, ölçme ve değerlendirme araçları sunması, öğrencilerin kendi aralarında etkileşimi için araçlar barındırması, kurumsal bir yapıya sahip olması ve sertifikasyon sağlayabilmesi ile web sitelerinden farklılaşır (Perifanou, 2015). İlk olarak 2008 yılında Siemens ve Downes tarafindan 2300 öğrenci ile yürütülen KAÇD’ler geçtiğimiz 10 yıl içerisinde oldukça yaygınlaşmıştır. KAÇD arama motoru olan Class Central'ın (2017) raporuna göre 33 büyük sağlayıcı tarafından 7000'in üzerinde KAÇD dünya genelinde erişime açıktır. Bunlardan Coursera'da 129 tanesi, Edx'te 27 tanesi ve FutureLearn'de 6 tanesi dil öğrenime yöneliktir. Geniş ölçekte uluslararası tanınırlığa sahip KAÇD platformlarından sadece Udemy'de yabancı dil olarak Türkçe dersleri bulunmaktadır. Türkçenin uzaktan öğretimi için halihazırda işlevsel olan Anadolu Üniversitesi'nin Anadil Türkçe Platformu ve Yunus Emre Enstitüsünün Türkçe Öğretim Portalı bulunmasına rağmen Türkiye menşeli bir KAÇD bulunmamaktadır. Bu bağlamda TÜBİTAK'ın da desteklediği Türkçenin Yabancı Dil Olarak Farklılaştırılmış Uzaktan Öğretimi projesi kapsamında araştırmacılar tarafından Şekil 1'de ekran görüntüsü sunulan Türkçe Öğreniyorum adlı bir KAÇD geliştirilmiş ve https://turkish.yasar.edu.tr/ adresinden ücretsiz olarak sunulmuştur. 


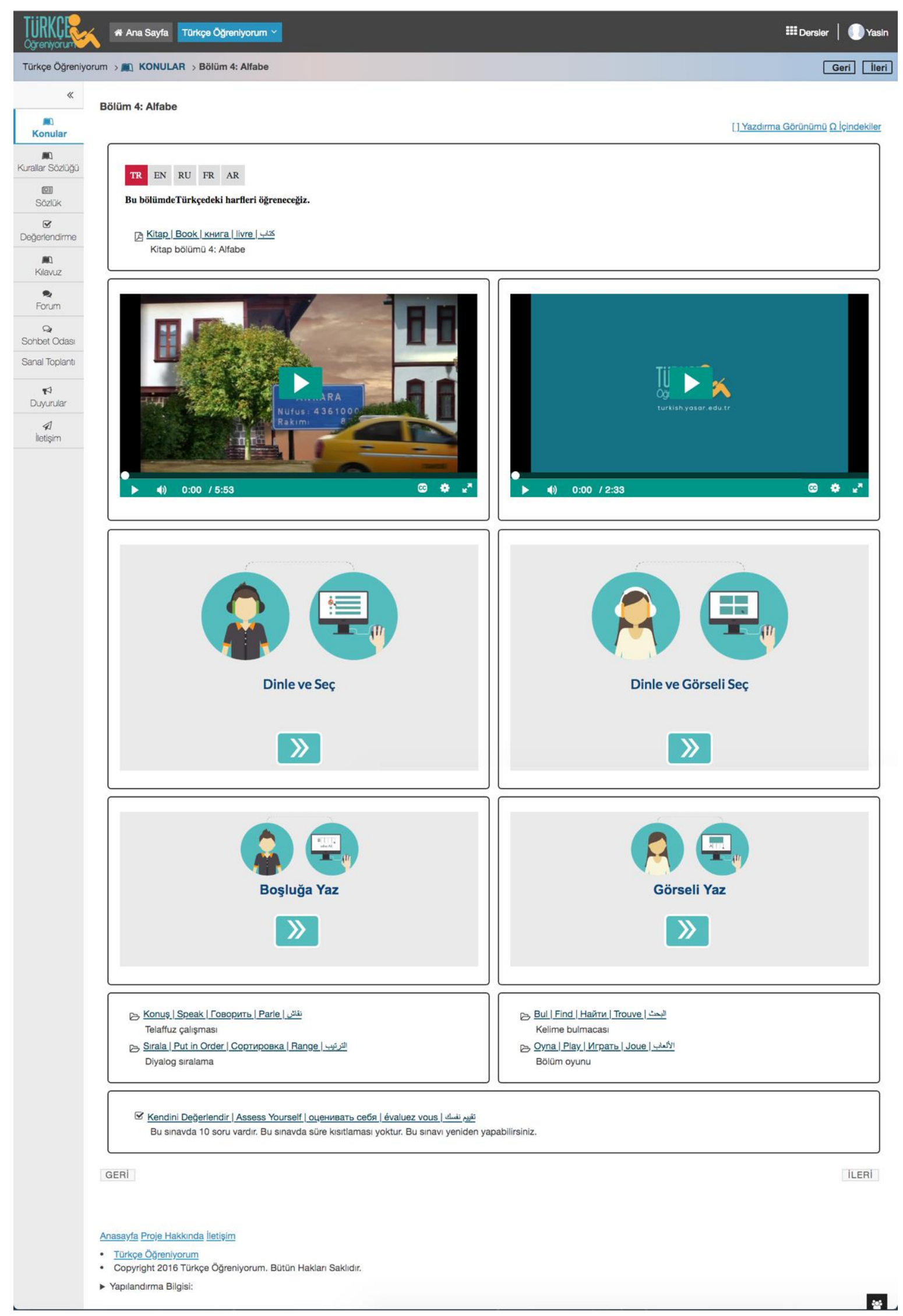

Şekil 1. Türkçe Öğreniyorum Sistemi Ekran Görüntüsü

Türkçe Öğreniyorum 115K270 proje kodu ile TÜBİTAK tarafindan desteklenmektedir. Proje kapsamında A1 seviyesinde 53 küçük bölüm geliştirilmiştir. Her bölümde 5 dakikalık bir ders videosu ile 2 dakikalık bir drama 
videosunun yanı sıra okuma, dinleme, yazma, telaffuz ve öz-değerlendirme etkinlileri yer almaktadır (Ozarslan ve Ozan, 2017). Ayrıca sistemde yaklaşık 40 oyun, 1500 kelime içeren A1 seviyesinde bir sözlük, toplamda yaklaşık 6000 soru, bir kurallar sözlüğü, bir forum ve sanal bir toplantı uygulaması mevcuttur. 40.000 kelimelik Türkçe metin; İngilizce, Arapça, Rusça ve Fransızca dillerine çevrilmiş ve öğrencilere 4 farklı dilde destek sunmuştur. Sistem; açık kaynak kodlu öğrenme ortamı Sakai CLE üzerinde Kaltura Video Platformu, Google Analitik ve bağlı servisler ile bütünleşik olarak çalışmaktadır. Sistemde alıştırma kayıtları, öğrenenin site ziyaretleri, araç kullanımları, gerçekleştirdiği denemeler ve bunlara verdiği cevaplar, göz attığı kaynaklar, öğrenenin demografik bilgileri ile öğrenen davranışlarına yönelik sayfa görüntüleme sayıları, sayfa çıkışları, davranış akışı, tercih edilen teknoloji (cihaz), işletim sistemi, ekran çözünürlüğü, video olayları (video görüntüleme süresi, oynatma sayısı, duraklatma ve atlama girişimleri, vb.) gibi pek çok veri tutulmaktadır. İçerik uzmanı, öğretim tasarımcısı, grafik tasarımcı, fotoğrafçı, video geliştirici, senarist, kameraman, yönetmen, post prodüksiyon uzmanı, oyuncu (aktör ve aktrisler), seslendirmen, çevirmen, multimedya geliştirici, sistem yöneticisi, yazılım uzmanı ve danışmandan rollerinde toplam 45 profesyonel projede görev almıştır.

30 Haziran 2018 itibarıyla Türkçe Öğreniyorum sisteminde 104 farklı ülke ve 136 farklı milletten öğrenen olarak 6254 adet kayıtlı kullanıcı mevcuttur. Bu çalışmada, yabancı dil olarak Türkçe öğrenen söz konusu 6254 kullanıcının profil analizi yapılmıştır. Yabancı dil olarak Türkçe öğrenmek isteyenlerin Türkçe öğrenme nedenleri, anadil, milliyet, eğitim seviyesi, çalışma durumu, yaşadıkları ülke, bildikleri yabancı dil sayısı, internet kullanım alışkanlıkları ve ilgi alanlarına dair dağılımların ve bunlar aralarındaki ilişkinin incelenmesi amaçlanmıştır. Çalışma ile alan uygulayıcıları ve politika geliştiricilerine çeşitliliği yüksek, örgün eğitimin dışındakileri de içeren, nitelikli ve kapsamlı veri sunmak ve karar verme süreçlerine katkı sağlamak hedeflenmektedir. Yabancılara Türkçe öğretimi alanyazınında hem yurtiçindeki hem de yurtdışındaki yabancıları örgün eğitim dışında kalanları da kapsayacak şekilde büyük ve çeşitlilik arz eden bir örneklem üzerinde çalışan başka bir yayın henüz yer almamaktadır. Alanyazındaki çalışmalar; yaygın olarak yüz yüze sınıflardaki öğrenciler ile sınırlı olduğundan ulaşılan katılımcı sayıları düşük ve çeşitliliği homojendir, katılımcı profilini yaygın olarak kursiyerler oluşturmaktadır (Aktaş ve Uzuner Yurt, 2015; Biçer, 2017; Bozkurt ve Uzun, 2015; Büyükikiz, 2014; Dönmez ve Gündoğdu, 2016; Erdem, Gün, Şengül ve Özkan, 2015). Bu bağlamda çalışma, Türkçe öğrenmek isteyen yabancılara dair dünya genelinden elde edilmiş kapsamlı verilere dayanan bir analiz sunması açısından önemlidir. Türkçe Öğreniyorum sisteminin duyurusu üniversite rektörlüğü tarafindan resmi kanalla Millî Eğitim Bakanlığı, Büyük Elçilikler, Dışişleri Bakanlığı, Yunus Emre Enstitüsü, Yurt Dışı Türkler Başkanlığı'na yapılıp sosyal medya kanalı ile ilgili ağlarda duyurulduktan sonra kullanıcı sayısı 6000'leri bulmuştur. Sistem resmi kanallar ile duyurulduğundan ve arkasında kurumsal bir destek bulunduğundan ilgili hedef kitleye erişildiği; bu bağlamda araştırmanın, Türkçe öğrenmek isteyen bilgi ve iletişim teknolojilerine erişimde sorun yaşamayan yetişkinlere dair temsil gücü yüksek olduğu söylenebilir.

\section{Yöntem}

\section{Araştırmanın Deseni}

Bu araştırma; Türkçe Ögrreniyorum kitlesel açık çevrimiçi dersine 30 Haziran 2017 - 30 Haziran 2018 tarihleri arasında kayıtlanan öğrenenlerin cinsiyet, yaş, Türkçeyi öğrenme nedenleri, anadil, milliyet, eğitim seviyesi, çalışma durumu, yaşadıkları ülke, bildikleri yabancı dil sayısı, internet kullanım alışkanlıkları ve ilgi alanları bağlamında profil analizinin belirlenmeye çalışıldığ betimleyici nitelikte bir araştırmadır. Araştırmada, Türkçe Öğreniyorum kitlesel çevrimiçi dersine kayıtlanan yabancıların özelliklerinin belirlenmesi için betimsel tarama yönteminin kesitsel tarama modeli kullanılmıştır. Kesitsel tarama modeli ile amaçlanan, incelenen olgunun zaman içindeki bir kesitinin özelliklerini betimlemektir (Özdemir, 2014).

\section{Katılımeılar}

Araştırmanın evrenini kitlesel açık çevrimiçi ders yoluyla yabancı dil olarak uzaktan Türkçe öğrenmek isteyenler oluşturmaktadır. Araştırma evreni hareketli durumda olup, katılımcıları sabit olmadığından güdümlü örnekleme yoluna gidilmiştir. Katılımcıları araştırma probleminin en tipik biçimde gözlenebileceği düşünülen, 30 Haziran 2017 - 30 Haziran 2018 tarihleri arasında Türkçe Öğreniyorum sistemine 104 farklı ülke ve 136 farklı milletten öğrenen olarak kaydolan 6254 kullanıcı oluşturmaktadır. Sistem, Türkçe Öğreniyorum adı altında kitlesel açık çevrimiçi ders olarak https://turkish.yasar.edu.tr/ adresinden ücretsiz olarak sunulmakta olup, kayitlanma için herhangi bir ön koşul ya da sınırlama söz konusu değildir. Kayıt aşamasında kullanıcılar araştırma hakkında bilgilendirmekte ve onayları alınmaktadır. Bu çalışmada sisteme gönüllü olarak kaydolmuş söz konusu 6254 kullanıcı, araştırmanın katılımcılarını oluşturmaktadır. Katılımcıların 1981'i (\% 31.68) kadın, 4115'i (\% 65.80) erkektir. 158 (\% 2.53) kişi cinsiyetini belirtmek istememiştir. Katılımcıların \% 4.35'i $(n=272) 18$ yaşının altında, \% 26.16'si $(n=1636) 18-24, \%$ 40.87'si $(n=2556) 25-34, \%$ 19.04'ü $(n=1191) 35-44$ yaşları arasında olup \% 9.58'i $(n=599)$ ise 45 yaş üstündedir. 


\section{Veri Toplama Aracı}

Verilerin toplamasında öğrenme yönetim sistemi için özelleştirilen ve İngilizce, Arapça, Rusça ve Fransızca olmak üzere 4 dilde sunulan Kayıt Formu kullanılmıştır. Form, projede çalışan 3 araştırmacı ve bursiyer olarak yer alan 2 içerik uzmanı tarafından geliştirilmiştir. Geçerlilik ve güvenirlik çalışmaları bağlamında biri ölçme değerlendirme, biri yabancılara Türkçe öğretimi anında iki uzmandan görüş alınmıştır. Alan uzmanlarının görüşleri çerçevesinde yapılan ilk revizyonun ardından form, pilot uygulamada öğrenenlerle paylaşılmış anlaşılmayan maddeler düzeltilerek son hali verilmiştir. Form ile yabancı dil olarak Türkçe öğrenmek isteyenlerin Türkçe öğrenme nedenleri, anadilleri, yaşadıkları ülkeler, eğitim seviyeleri, çalışma durumları, bildikleri yabancı diller, internet kullanım alışkanlıkları, çevrimiçi ders geçmişleri, ilgi alanları, Türkçe önbilgileri, doğum tarihleri ve cinsiyetlerine dair veriler toplanmıştır. İlgili form Türkçe Öğreniyorum sisteminde kullanıldığı şekliyle Tablo 1'de paylaşılmıştır:

Tablo 1

Kayıt Formunda Veri Toplanan Konular ve Sorulart

\begin{tabular}{|c|c|}
\hline Veri Toplanan Konular & Soru \\
\hline Çevrimiçi ders geçmişi & $\begin{array}{l}\text { Çevrimiçi ders aldınız mı? } \\
\text { • Hayır } \\
\text { • } \\
\text { - Çevrimiçi ders deneyimim oldu } \\
\text { Çevrimiçi dersler aldım }\end{array}$ \\
\hline $\begin{array}{l}\text { Bilgisayar kullanım } \\
\text { amaçları }\end{array}$ & 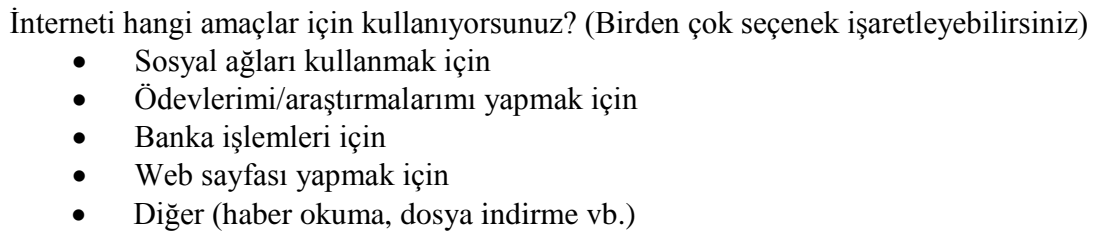 \\
\hline
\end{tabular}

Türkçe önbilgisi

Türkçe öğrenme nedenleri

Türkçe biliyor musunuz?

Aşağıda bir dilin öğrenme seviyeleri belirtilmiştir. Siz kendinizi hangi seviyede görüyorsunuz, işaretleyiniz.

- $\quad$ 22: Anadilim gibi konuşurum

- $\mathrm{C} 1$ : Karmaşık konularda ve mesleki alanda kendimi akıcı bir şekilde ifade edebilirim.

- B2: Ana dili Türkçe olanlarla rahatlıkla anlaşabilirim.

- B1: Genel olarak kendimi ifade edebilirim, bir konu ya da olay hakkında bilgi verebilirim.

- $\quad$ A2: Günlük ihtiyaçlarımı karşılayacak kadar konuşabilirim.

- A1: Kendimi tanıtabilirim. Basit soruları cevaplayabilirim.

- Sadece birkaç kelime Türkçe biliyorum.

- Hiç bilmiyorum.

Neden Türkçe öğrenmek istiyorsunuz? (Birden çok seçenek işaretleyebilirsiniz)

- $\quad$ Akademik gerekçelerle (Türkiye'de çalışmak, okumak, burs almak gibi)

- İş gereği (ticaret, çalışma gibi)

- Genel amaçlı (Kişisel ilgi, seyahat, kültürel merak, Türkçe konuşan akraba, arkadaş, komşu sahibi olmak gibi)

Anadiliniz nedir?

Anadilinizden başka bir dili (veya dilleri) konuşabiliyor musunuz?

- Hayır

- $\quad$ Evet.

(Evet cevabı verilmiş ise)

- Lütfen bildiğiniz dili seçiniz

- $\quad$ Seviyenizi giriniz

Bildiği diller

Seviyeniz

C2: Anadilim gibi konuşurum

C1: Karmaş1k konularda ve mesleki alanda kendimi akıcı bir şekilde ifade edebilirim.

B2: Ana dili konuşurlarıyla rahatlıkla anlaşabilirim.

B1: Genel olarak kendimi ifade edebilirim, bir konu ya da olay hakkında bilgi verebilirim.

A2: Günlük ihtiyaçlarımı karşılayacak kadar konuşabilirim.

A1: Kendimi tanıtabilirim. Basit soruları cevaplayabilirim

Bir dil daha ekle 
Tablo 1 -devam

\begin{tabular}{|c|c|}
\hline Veri Toplanan Konular & Soru \\
\hline Memleketi ve yaşadığı ülke & $\begin{array}{l}\text { Memleketiniz (Home country) } \\
\text { (Şu an) Nerede yaşıyorsunuz? }\end{array}$ \\
\hline Doğum tarihi & Doğum tarihiniz \\
\hline Cinsiyeti & $\begin{aligned} \text { Cinsiyetiniz } \\
$\[ \quad \text { Erkek } \]$ \\
\text { - Kadın } \\
\text { - } \quad \text { Belirtmek istemiyorum }\end{aligned}$ \\
\hline Çalışma durumu & $\begin{aligned} & \text { Şu anki durumunuz? } \\
& \text { • Çalışıyor } \\
& \text { • } \text { Çalışmıyor } \\
& \text { - } \text { Öğrenci } \\
& \text { - } \text { Belirtmek istemiyorum }\end{aligned}$ \\
\hline Eğitim durumu & $\begin{array}{l}\text { En son tamamladığınız okulun eğitim düzeyi ya da derecesi nedir? Hâlihazırda kayıtlı } \\
\text { öğrenciyseniz aldığınız son derece. } \\
\text { - İlköğretim/Ortaöğretim } \\
\text { - Lise ya da Dengi okul } \\
\text { - Önlisans/Lisans } \\
\text { - Yüksek Lisans } \\
\text { - Doktora }\end{array}$ \\
\hline İlgi alanları & $\begin{array}{cl}\text { Ne tarz konular ilginizi çekiyor? } \\
\text { - İş } \\
\text { - } \\
\text { - } \\
\text { - } \\
\text { - } & \text { Eülenyadilim ve ve yeknaşam gelişmeler } \\
\text { - } & \text { Spor } \\
\text { - } & \text { Edebil ve kültür } \\
& \end{array}$ \\
\hline
\end{tabular}

\section{Veri Toplama Süreci}

Veri toplama süreci 30 Haziran 2017 - 30 Haziran 2018 tarihleri arasında gerçekleşmiștir. Türkçe Öğreniyorum kitlesel açık çevrimiçi dersine kayıtlanan kullanıcıların ilgili sorulara kayıt aşamasında 4 adımda cevap vermesi sağlanmıştır. Veriler elektronik ortamda öğrenme yönetim sisteminin profil yönetim aracına uyumlu şekilde veri tabanında depolanmıştır. Veriler sistemden kimliksizleştirilerek analiz için dışarı aktarılmıştır. Yanıtlar, bireysel olarak tanımlanmamıştır, tüm cevaplar bir araya getirilerek grup halinde analiz edilmiş ve raporlanmıştır.

\section{Veri Analizi}

Veri analizinde betimsel istatistik yöntemlerinin yanı sıra istatistiksel olarak anlamlı farkl1lıkların olup olmadığını incelemek için ki-kare analizleri yapılmış, etki büyüklüğünün ölçümü Cramer's $V$ kullanılarak (Özsoy ve Özsoy, 2013) gerçekleştirilmiştir. Birden çok yanıtın verilebildiği bölümler için çoklu cevap analizi veri seti tanımlanması yoluna gidilmiş̧ir. Verilerin analizinde, birinci tip hatayı kontrol etmek amacıyla Bonferroni düzeltmesi yapılmıştır.

\section{Bulgular}

Araştırma sürecinde elde edilen bulgular; yabancı dil olarak Türkçe öğrenmek isteyenlerin Türkçe öğrenme nedenleri, anadilleri, milliyetleri ve yaşadıkları ülkeler, eğitim seviyeleri, çalışma durumları, bildikleri yabancı diller, internet kullanım alışkanlıkları ve ilgi alanları başlıkları altında ele alınmıştır.

\section{Kullanıcıların Yabancı Dil Olarak Türkçe Öğrenme Nedenleri}

Kayıt formunda yabancı dil olarak Türkçe öğrenme nedenleri akademik, iş ve genel şeklinde alınmıştır. Kullanıcılara çoklu seçim yapabilmelerine imkân sağlanmıştır. Yabancı dil olarak Türkçe öğrenmek isteyenlerin $(n=6254) \% 62.77$ 'si $(f=3926)$ genel amaçlarla (Kişisel ilgi, seyahat, kültürel merak, Türkçe konuşan akraba, arkadaş, komşu sahibi olmak gibi), \% 54.28'i $(f=3395)$ akademik gerekçelerle (Türkiye'de çalışmak, okumak, burs almak gibi) \% 44.42'si $(f=2778)$ de iş için (Ticaret, çalışma gibi) Türkçe öğrendiğini belirtmiştir. Türkçe öğrenmek isteyenlerin \% 21.60'1 $(f=1351)$ sadece akademik gerekçelerle Türkçe öğrenirken, \% 23.49'u $(f=$ 1469) sadece genel amaçlarla Türkçe öğrenmektedir. Sadece iş gereği Türkçe öğrenenler \% 10.95'tir $(f=685)$. 
Katılımcıların Türkçe öğrenme nedenleri; Türkiye'de ve Türkiye dışında yaşama durumu hariç anadili, bildiği yabancı dil ve sayısı, eğitim seviyesi, çalışma durumu, internet kullanım alışkanlıkları ve ilgi alanları bağlamında anlamlı fark göstermemektedir. Tablo 2'de görüldüğü gibi katılımcıların Türkçeyi öğrenme nedenleri Türkiye'de ve Türkiye dışında yaşama durumlarına göre incelendiğinde iki grup arasında anlamlı bir fark ortaya çıkmıştır $(\chi 2(3)=360.039, p<.001$, Cramer's $V=.25)$.

Tablo 2

Katılımcıların Türkçeyi Öğrenme Nedenlerinin Türkiye’de ve Türkiye Dışında Yaşama Durumuna Göre Karşılaştırılması*

\begin{tabular}{|c|c|c|c|c|c|c|c|}
\hline & & & $\begin{array}{c}\text { Türkiye Dişında } \\
\text { Yaşayan }\end{array}$ & $\begin{array}{l}\text { Türkiye'de } \\
\text { Yaşayan }\end{array}$ & Toplam & Test İstatistiği & $\begin{array}{c}\text { İlişki } \\
\text { Katsayısı }\end{array}$ \\
\hline \multirow{8}{*}{$\begin{array}{l}\text { Türkçeyi Öğrenme } \\
\text { Nedenleri }\end{array}$} & \multirow{2}{*}{ Akademik } & $f$ & 378 & 973 & 1351 & \multirow{8}{*}{$\chi^{2}=360.039$} & \multirow{8}{*}{$V=.25$} \\
\hline & & $\%$ & 27.98 & 72.02 & 21.60 & & \\
\hline & \multirow{2}{*}{ İş Gereği } & $f$ & 123 & 562 & 685 & & \\
\hline & & $\%$ & 17.96 & 82.04 & 10.95 & & \\
\hline & \multirow{2}{*}{ Genel Amaçlı } & $f$ & 700 & 769 & 1469 & & \\
\hline & & $\%$ & 47.65 & 52.35 & 23.49 & & \\
\hline & \multirow{2}{*}{ Toplam } & $f$ & 1201 & 2304 & 3505 & & \\
\hline & & $\%$ & 34.27 & 65.73 & 56.04 & & \\
\hline
\end{tabular}

* Sadece Akademik, İş Gereği ve Genel Amaçlı nedenleri belirtenlerin karşılaştırılmasını içermektedir.

İş gereği Türkçe öğrenmek isteyenlerin \% 82.04'ü ve akademik gerekçelerle Türkçe öğrenmek isteyenlerin \% 72.02'si Türkiye'de yaşayan yabancılardır. Genel amaçlı Türkçe öğrenmek isteyenlerin çoğunluğunu (\% 52.35) az bir farkla Türkiye'de yaşayan yabancılar oluşturmaktadır. Türkiye'de yaşayanların Türkçeyi öğrenme nedenleri akademik ve iş gereği seçeneğinde yoğunlaşırken Türkiye dışında yaşayanların tercihi kişisel ilgi, seyahat, kültürel merak, Türkçe konuşan akraba, arkadaş, komşu sahibi olmak gibi genel amaçlıdır.

Yabancı Dil Olarak Türkçe Öğrenmek İsteyen Kullanıcıların Anadilleri

Yabancı dil olarak Türkçe öğrenenlerin \% 81.55'inin $(n=5100)$ anadili Arapçadır. Anadil bağlamında dağılım Tablo 3'te verilmiştir. Arapçayı sırasıyla İngilizce $(\% 2.94, n=184)$ ve Farsça $(\% 1.58, n=99)$ takip etmektedir.

Tablo 3

Yabancı Dil Olarak Türkçe Öğrenenlerin Dil Ailesi Bă̆lamında Dă̆ılımı

\begin{tabular}{|c|c|c|c|}
\hline & Ana Dili & $N(6254)$ & $\%$ \\
\hline 1. & Arapça & 5100 & 81.55 \\
\hline 2. & İngilizce & 184 & 2.94 \\
\hline 3. & Farsça & 99 & 1.58 \\
\hline 4. & Süryanice & 78 & 1.25 \\
\hline 5. & İspanyolca & 74 & 1.18 \\
\hline 6. & Rusça & 65 & 1.04 \\
\hline 7. & Fransizca & 64 & 1.02 \\
\hline 8. & Endonezya Dili & 45 & 0.72 \\
\hline 9. & Somali Dili & 40 & 0.64 \\
\hline 10. & Kürtçe & 34 & 0.54 \\
\hline 11. & Almanca & 32 & 0.51 \\
\hline 12. & Urduca & 25 & 0.40 \\
\hline 13. & İtalyanca & 23 & 0.37 \\
\hline 14. & Yunanca & 22 & 0.35 \\
\hline 15. & Çince & 17 & 0.27 \\
\hline 16. & Diğer & 352 & 5.63 \\
\hline
\end{tabular}

\section{Yabancı Dil Olarak Türkçe Öğrenmek İsteyenlerin Milliyeti ve Yaşadıkları Ülke}

Tablo 4'te verildiği üzere sisteme çoğunlukla Arap yarımadasından ve Türkiye'den bağlanılmaktadır. Sisteme \% $50.98(n=3188)$ oranında Suriyeliler kayıtlanmıştır. Suriyeli olduğunu belirtenlerden sadece \% 2.13'si $(n=$ 133) Suriye'de yaşadığını belirtmiştir. Yabancı dil olarak Türkçe öğrenmek isteyenlerin çoğunluğu $(\% 66.49, n$ = 4158) Türkiye'de yaşamaktadır. 
Tablo 4

Yabancı Dil Olarak Türkçe Öğrenmek İsteyenlerin Milliyetleri ve Yaşadıkları Ülkeye Göre Dăğllımı*

\begin{tabular}{|c|c|c|c|c|c|}
\hline & & Milliyeti & $\%$ & Yaşadı̆̆ 1 Yer & $\%$ \\
\hline 1. & Suriye & 3188 & 50.98 & 133 & 2.13 \\
\hline 2. & Irak & 405 & 6.48 & 129 & 2.06 \\
\hline 3. & Misır & 345 & 5.52 & 183 & 2.93 \\
\hline 4. & Yemen & 296 & 4.73 & 91 & 1.46 \\
\hline 5. & Filistin & 181 & 2.89 & 51 & 0.82 \\
\hline 6. & Cezayir & 176 & 2.81 & 129 & 2.06 \\
\hline 7. & Fas & 163 & 2.61 & 137 & 2.19 \\
\hline 8. & Ürdün & 106 & 1.69 & 85 & 1.36 \\
\hline 9. & Suudi Arabistan & 91 & 1.46 & 336 & 5.37 \\
\hline 10. & İran & 79 & 1.26 & 26 & 0.42 \\
\hline 11. & Tunus & 63 & 1.01 & 45 & 0.72 \\
\hline 12. & Afganistan & 61 & 0.98 & 10 & 0.16 \\
\hline 13. & ABD & 56 & 0.90 & 52 & 0.83 \\
\hline 14. & Endonezya & 45 & 0.72 & 29 & 0.46 \\
\hline 15. & Somali & 41 & 0.66 & 16 & 0.26 \\
\hline 16. & Ukrayna & 37 & 0.59 & 22 & 0.35 \\
\hline 17. & Almanya & 33 & 0.53 & 37 & 0.59 \\
\hline 18. & Kuveyt & 23 & 0.37 & 32 & 0.51 \\
\hline 19. & Birleşik Arap Emirlikleri & 8 & 0.13 & 45 & 0.72 \\
\hline 20. & Türkiye & & & 4158 & 66.49 \\
\hline
\end{tabular}

* Milliyete göre ilk 20 listede paylaşııııștır.

\section{Yabancı Dil Olarak Türkçe Öğrenmek İsteyenlerin Eğitim Seviyeleri}

Yabancı dil olarak Türkçe öğrenmek isteyenlerin \% 10.92'si $(n=683)$ ilköğretim/ortaöğretim, \% 31.90'1 $(n=$ 1933) lise ya da dengi okul, \% 44.48'i $(n=2782)$ önlisans / lisans, \% 11.12'si $(n=696)$ yüksek lisans ve \% 2.56'sı $(n=160)$ doktora derecesine sahiptir. Eğitim seviyesi Türkiye'de ve Türkiye dışında yaşama durumuna göre incelendiğinde iki grup arasında anlamlı bir farklılık olduğu görülmüştür $(\chi 2(3)=237.104, p<.001$, Cramer's $V=.20)$. Katılımcıların eğitim seviyelerinin Türkiye'de ve Türkiye dişında yaşama durumuna göre karşıllaştırılması Tablo 5 'te sunulmuştur.

Tablo 5

Katılımcıların Eğitim Seviyelerinin Türkiye’de ve Türkiye Dışında Yaşama Durumuna Göre Karşılaştırılması

\begin{tabular}{|c|c|c|c|c|c|c|c|}
\hline & & & $\begin{array}{c}\text { Türkiye Dışında } \\
\text { Yaşayan }\end{array}$ & $\begin{array}{c}\text { Türkiye'de } \\
\text { Yaşayan }\end{array}$ & Toplam & Test İstatistiği & $\begin{array}{c}\text { İlişki } \\
\text { Katsayısı }\end{array}$ \\
\hline \multirow{12}{*}{ Eğitim Durumu } & \multirow{2}{*}{ İlköğretim/Ortaöğretim } & $n$ & 112 & 571 & 683 & \multirow{12}{*}{$\chi^{2}=237.104$} & \multirow{12}{*}{$V=.20$} \\
\hline & & $\%$ & 16.40 & 83.60 & 10.92 & & \\
\hline & \multirow{2}{*}{ Lise ya da Dengi Okul } & $n$ & 570 & 1363 & 1933 & & \\
\hline & & $\%$ & 29.50 & 70.50 & 30.91 & & \\
\hline & \multirow{2}{*}{ Önlisans/Lisans } & $n$ & 969 & 1813 & 2782 & & \\
\hline & & $\%$ & 34.80 & 65.20 & 44.48 & & \\
\hline & \multirow{2}{*}{ Yüksek Lisans } & $n$ & 354 & 342 & 696 & & \\
\hline & & $\%$ & 50.90 & 49.10 & 11.13 & & \\
\hline & \multirow{2}{*}{ Doktora } & $n$ & 91 & 69 & 160 & & \\
\hline & & $\%$ & 56.90 & 43.10 & 2.56 & & \\
\hline & \multirow{2}{*}{ Toplam } & $n$ & 2096 & 4158 & 6254 & & \\
\hline & & $\%$ & 33.51 & 66.49 & 100 & & \\
\hline
\end{tabular}

Tablo 5'te görüldüğü üzere eğitim durumu ilköğretim/ortaöğretim seviyesinde olanların \% 83.60'1 $(n=571)$, lise ya da dengi okul seviyesinde olanların \% 70.50'si $(n=1363)$ ve önlisans / lisans seviyesinde olanların \% 65.20'si $(n=1813)$ Türkiye'de yaşayan yabancılardır. Lisansüstü eğitim durumunda ise yüksek lisans seviyesinde olanların \% $50.90(n=354)$ ve doktora seviyesinde olanların \% 56.90’1 $(n=91)$ Türkiye dışında yaşayanlardır.

\section{Yabancı Dil Olarak Türkçe Öğrenmek İsteyenlerin Çalışma Durumu}

Kayıt formunda çalışma durumu; çalışıyorum, çalışmıyorum, öğrenciyim ve belirtmek istemiyorum şeklinde alınmıştır. Kullanıcılar yalnızca bir seçenek işaretleyebilmektedirler. Tablo 6'da verildiği üzere yabancı dil olarak Türkçe öğrenmek isteyenlerin \% 44.27'si $(n=2769)$ çalışmaktadır. \% 28.53'ü $(n=1784)$ öğrencidir. \% 15.32 'si ( $n=958$ ) ise çalışmadığını belirtmiştir. Çalışma durumu Türkiye'de ve Türkiye dışında yaşamaya göre incelendiğinde çalışan, çalışmayan ve öğrenci olan gruplar arasında anlamlı bir farklılık olduğu görülmüştür 
$(\chi 2(2)=76.922, p<.001$, Cramer's $V=.18)$. Katılımcıların çalışma durumunun Türkiye'de ve Türkiye dışında yaşama durumuna göre karşılaştırılması ise Tablo 6'da sunulmuştur.

Tablo 6

Katılımcıların Çalışma Durumunun Türkiye'de ve Türkiye Dışında Yaşama Durumuna Göre Karşılaştırılması

\begin{tabular}{|c|c|c|c|c|c|c|c|}
\hline & & & $\begin{array}{c}\text { Türkiye Dışında } \\
\text { Yaşayan }\end{array}$ & $\begin{array}{l}\text { Türkiye'de } \\
\text { Yaşayan }\end{array}$ & Toplam & Test İstatistiği & $\begin{array}{c}\text { İlişki } \\
\text { Katsayısı }\end{array}$ \\
\hline \multirow{10}{*}{ Çalışma Durumu } & \multirow{2}{*}{ Çalışmayan } & $n$ & 231 & 727 & 958 & \multirow{10}{*}{$\chi^{2}=76.922$} & \multirow{10}{*}{$V=.18$} \\
\hline & & $\%$ & 24.11 & 75.89 & 15.32 & & \\
\hline & \multirow{2}{*}{ Çalışan } & $n$ & 903 & 1866 & 2769 & & \\
\hline & & $\%$ & 32.61 & 67.39 & 44.27 & & \\
\hline & \multirow{2}{*}{ Öğrenci } & $n$ & 721 & 1063 & 1784 & & \\
\hline & & $\%$ & 40.41 & 59.59 & 28.53 & & \\
\hline & \multirow{2}{*}{ Belirtmeyen } & $n$ & 241 & 502 & 743 & & \\
\hline & & $\%$ & 32.44 & 67.56 & 11.88 & & \\
\hline & \multirow{2}{*}{ Toplam } & $n$ & 2096 & 4158 & 6254 & & \\
\hline & & $\%$ & 33.51 & 66.49 & 100 & & \\
\hline
\end{tabular}

Tablo 6'da görüldüğü üzere çalışmayanların \% 75.89'u ve çalışanların \% 67.39'unu Türkiye'de yaşayan yabancılar oluşturmaktadır. Öğrencilerin \% 59.59'u Türkiye'de yaşamaktadır. Çalışma durumunu belirtmek istemeyenlerin büyük bir bölümü (\% 67.56) Türkiye'de yaşayanlardır.

\section{Yabancı Dil Olarak Türkçe Öğrenmek İsteyenlerin Bildiği Yabancı Dil Sayısı}

Yabancı dil olarak Türkçe öğrenmek isteyenlerin \% 60.70'i $(n=3796)$ başka bir yabancı dil bilmemektedir. Katılımcıların \% 32.08'i $(n=2006)$ halihazırda bir yabanc1 dil, \% 5.28'i $(n=330) 2$ yabancı dil ve \% 1.95 'i $(n$ $=122) 3$ ve üzerinde yabancı dil bilmektedir.

\section{Türkçe Öğrenmek İsteyenlerin İnternet Kullanım Alışkanlıkları}

İnternet kullanım alışkanlıkları; çevrimiçi ders deneyimi, sosyal ağ kullanımı, ödev/araştırma yapma, bankacılık işlemleri, web sayfası yapma ve diğer (haber okuma, dosya indirme gibi genel amaçlar) olarak incelenmiştir.

Yabancı dil olarak Türkçe öğrenmek isteyenlerin büyük bir çoğunluğunun (\% 73.82) çevrimiçi bir ders deneyimi bulunmamaktadır. Bir çevrimiçi ders deneyimi olanların oranı \% 20.39 iken, birden fazla çevrimiçi ders deneyimi olan katılımcı (\% 5.79) azdır.

Çevrimiçi ders deneyimi cinsiyet $(\chi 2(4)=2.083, p=0.35)$ ve çalışma durumu $\left(\chi^{2}(4)=2.877, p=0.58\right)$ bağlamında anlamlı fark göstermemektedir. Çevrimiçi ders deneyimi Türkiye'de ve Türkiye dışında yaşama durumuna göre incelendiğinde ise iki grup arasında anlamlı bir farkl1lı olduğu görülmüş̧tür $(\chi 2(2)=22.022, p$ $<.001$ Cramer's $V=.06$ ). Katılımcıların çevrimiçi ders deneyimlerinin Türkiye'de ve Türkiye dışında yaşama durumuna göre karşılaştırılması Tablo 7'de sunulmuştur.

Tablo 7

Yabancı Dil Olarak Türkçe Öğrenmek İsteyenlerin Türkiye'de ve Türkiye Dışında Yaşama Durumuna Göre Çevrimiçi Ders Deneyimi

\begin{tabular}{llcccccc}
\hline & & Türkiye Dişında & Türkiye'de \\
Yaşayan & Yaşayan & Toplam & Test İstatistiği $\begin{array}{c}\text { İlişki } \\
\text { Katsayısı }\end{array}$ \\
\hline & Çevrim içi ders & $n$ & 1471 & 3146 & 4617 & & \\
& deneyimim yok & $\%$ & 31.86 & 68.14 & 73.82 & & \\
& Bir çevrimiçi ders & $n$ & 482 & 793 & 1275 & $\chi 2=22.022$ & \\
Çevrimiçi Ders & deneyimim oldu & $\%$ & 37.80 & 62.20 & 20.39 & $\chi$ & \\
Deneyimi & Birden fazla çevrimiçi & $n$ & 143 & 219 & 362 & $p<.001$ & \\
& ders aldım & $\%$ & 39.50 & 60.50 & 5.79 & & \\
& Toplam & $n$ & 2096 & 4158 & 6254 & & \\
& & $\%$ & 33.51 & 66.49 & 100 & & \\
\hline
\end{tabular}

Tablo 7'de görüldüğü üzere çevrimiçi ders deneyimi olmayanların \% 68.14'ü, bir çevrimiçi ders deneyimi olanların \% 62.20'si ve birden fazla çevrimiçi olanların \% 60.50'si Türkiye'de yaşamaktadır.

Çevrimiçi Ders Deneyimi eğitim durumlarına göre incelendiğinde iki grup arasında anlamlı bir farklılık olduğu görülmüştür $(\chi 2(6)=150.834, p<.001$ Cramer's $V=.12)$. Katılımcıların çevrimiçi ders deneyimlerinin eğitim durumuna göre karşılaştırılması ise Tablo 8'de sunulmuş̧tur. 


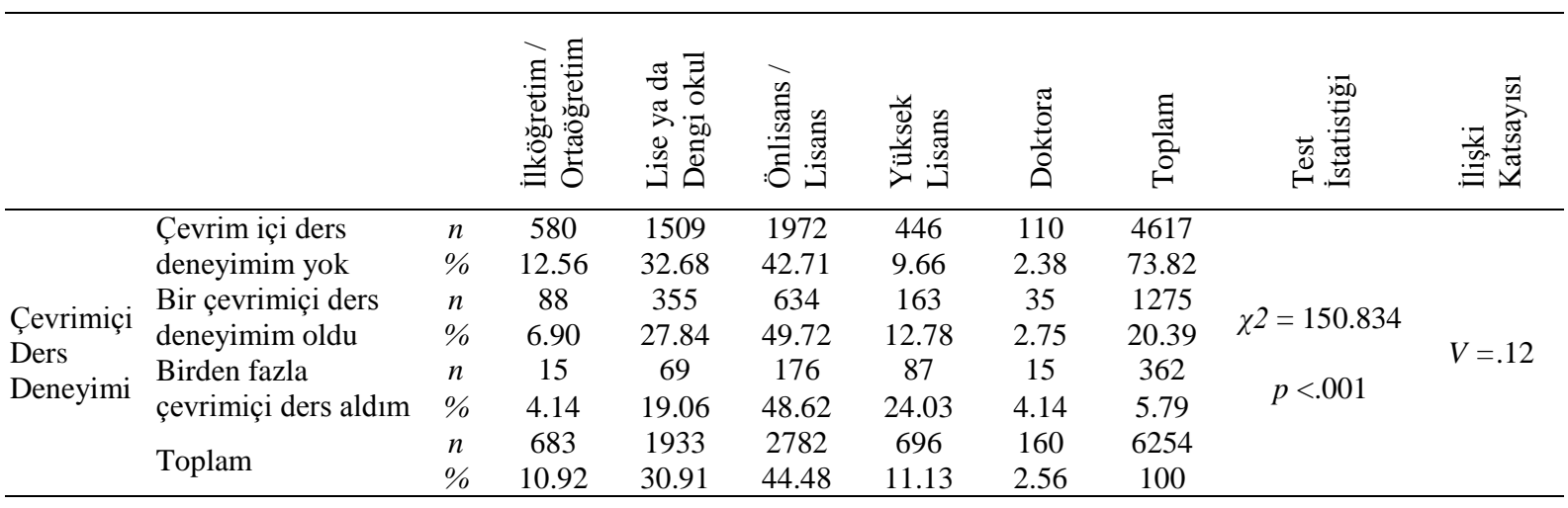

Çevrimiçi ders deneyimi olmayanların çoğunluğunu önlisans / lisans $(\% 42.71, n=1972)$ ve lise ya da dengi okul (\% 32.68, $n=1509$ ) seviyesindedir. Bir çevrimiçi ders deneyimi olanların \% 49.72'si $(n=634)$ ve birden fazla çevrimiçi ders alanların \% 48.62'si $(n=176)$ önlisans / lisans seviyesinde eğitim durumuna sahiptir.

İnternet kullanım alışkanlıkları; çevrimiçi ders deneyimi, sosyal ağ kullanımı, ödev/araştırma yapma, bankacılık işlemleri, web sayfası yapma ve diğer (haber okuma, dosya indirme gibi genel amaçlar) olarak incelenmiştir. Yabancı dil olarak Türkçe öğrenmek isteyenlerin \% 68.00'i $(f=4253)$ sosyal ağları kullanmaktadır. \% 64.01'i $(f$ = 4003) haber okuma, dosya indirme gibi genel amaçlar için interneti kullandığını belirtmiş̧tir. \% 56.00'sı $(f=$ 3502) ödev/araştırma için interneti kullanmaktadır. Sadece \% 18.00'1 $(f=1126)$ internet üzerinden bankacılık işlemleri gerçekleş̧irmektedir. \% 9.99'u $(f=625)$ ise web sayfası geliştirebilmektedir. Cinsiyet bağlamında $(\chi 2(5)=65.053, p<.001)$ erkekler bankacılık işlemleri ve web gelişme için kadınlara oranla daha yüksek kullanıma sahipken, kadınlar interneti erkeklere göre daha yüksek oranla ödev/araştırma yapmak için tercih etmektedir.

\section{Yabancı Dil olarak Türkçe Öğrenmek İsteyenlerin İlgi Alanları}

Türkçe öğrenmek isteyenlerin ilgi alanları iş, dünyadaki gelişmeler, eğlence ve yaşam, bilim ve teknoloji, spor, dil ve kültür ile edebiyat bağlamında ele alınmıştır. Ardından ilgi alanının cinsiyet, eğitim durumu, yaşadıkları ülke (yurtiçi veya yurt dışı bağlamında), Türkçe öğrenme amaçları ve çalışma durumunu ile ilişkisi incelenmiştir.

Yabancı dil olarak Türkçe öğrenenlerin ilgi alanları cinsiyet bağlamında incelendiğinde anlamlı bir farklılık olduğu görülmüştür $\left(\chi^{2}(7)=798.281, p<.001\right)$. Gruplar arası ortalama farklarının etki büyüklüğünün $\dot{I}_{S ̧}$ (Cramer's $V=.25$ ), eğlence ve yaşam (Cramer's $V=.10$ ), bilim ve teknoloji (Cramer's $V=.10$ ), spor (Cramer's $V=.12$ ), dil ve kültür (Cramer's $V=.15$ ) için yeterli büyüklükte; dünyadaki gelişmeler (Cramer's $V$ $=.07$ ) ve edebiyat (Cramer's $V=.07$ ) için düşük olduğu belirlenmiştir. Erkeklerin \% 70.09, kadınların \% 43.82'si iş; erkeklerin \% 44.18, kadınların \% 37.05'i dünyadaki gelişmeler; erkeklerin \% 47.56, kadınların \% 37.51 'i bilim ve teknoloji ve erkeklerin \% 26.73'ü, kadınların \% 15.90'1 spor olmak üzere erkekler kadınlara oranla bu alanlara daha çok ilgi göstermektedirler. Bunun yanında kadınların \% 48.36'sı, erkeklerin \% 36.04'ü eğlence ve yaşam; kadınların \% 74.91'i, erkeklerin \% 59.03'ü dil ve kültür ve kadınların \% 32.10'u, erkeklerin $\% 25.88$ 'i edebiyat olmak üzere kadınlar erkeklere oranla bu alanlarda daha ilgili oldukları görülmüsstür.

Yabancı dil olarak Türkçe öğrenenlerin ilgi alanları eğitim durumları bağlamında incelendiğinde anlamlı bir fark olduğu görülmüştür $(\chi 2(21)=487.329, p<.001)$. Lisansüstü eğitim alanların $\% 49.70$ 'i dünyadaki gelişmeler (Cramer's $V=.12$ ) ve $\% 51.70$ 'i bilim ve teknoloji (Cramer's $V=.10$ ) alanlarına daha ilgili oldukları tespit edilmiştir. Önlisans / lisans düzeyinde eğitime sahip olanların \% 68.16'sı iş (Cramer's $V=.14$ ) alanına diğerlerine oranla daha çok ilgi göstermektedir. Önlisans / lisans eğitim alanların \% 40.04'i ve lise ya da dengi okul düzeyinde eğitim alanların \% 41.30'u ise eğlence ve yaşam (Cramer's $V=.04$ ) konuları ile diğerlerine göre düşük bir oranla da olsa daha fazla ilgilendikleri saptanmıştır. Lise ya da dengi okul düzeyinde eğitime sahip olanların \% 25.55'i spor alanına (Cramer's $V=.04$ ) diğer eğitim düzeylerine sahip olanlara göre daha ilgilidir. Kadınlar, eğitim düzeyi fark etmeksizin eğlence ve yaşam ile dil ve kültür alanlarına erkeklere oranla daha çok ilgi göstermektedirler. Edebiyat alanına ise önlisans / lisans eğitimi alan kadınlar, \% 16.30 ile diğerlerine göre daha ilgilidir. Erkekler ise eğitim düzeyi fark etmeksizin iş alanına kadınlara oranla daha çok ilgi göstermektedir.

Yabancı dil olarak Türkçe öğrenenlerin ilgi alanları yaşadıkları ülke bağlamında incelendiğinde anlamlı bir farklılık olduğu görülmüştür $(\chi 2(7)=154.162, p<.001)$. Türkiye'de yaşadığını belirten yabancıların \% 65.06'sı, Türkiye dışında yaşadığını belirten yabancıların \% 53.29'u iş (Cramer's $V=.12$ ) alanına; Türkiye dışında yaşadığını belirten yabancıların \% 44.70'i, Türkiye'de yaşadığını belirten yabancıların \% 40.38'i 
dünyadaki gelişmeler (Cramer's $V=.04)$, Türkiye dışında yaşadığını belirten yabancıların \% 43.32'si, Türkiye'de yaşadığını belirten yabancıların \% 38.82'si eğlence ve yaşam (Cramer's $V=.05$ ) ve Türkiye dişında yaşadığını belirten yabancıların \% 70.04'ü, Türkiye'de yaşadığını belirten yabancıların \% 61.42'si dil ve kültür (Cramer's $V=.09$ ) ilgi alanlarına düşükte olsa daha ilgili gözükmektedir.

Yabancı dil olarak Türkçe öğrenenlerin ilgi alanları Türkçe öğrenme amaçları bağlamında incelendiğinde anlamlı bir farklılık olduğu görülmüştür $(\chi 2(21)=3479.327, p<.001)$. Türkçeyi iş gereği öğrenmek isteyenlerin \% 87.01'i iş (Cramer's $V=.48$ ) alanına, genel amaçlı öğrenenlerin \% 48.96's'sı eğlence ve yaşam (Cramer's $V=.23$ ) alanına yöneldiği görülmüştür. Bilim ve teknoloji ilgi alanına ise akademik amaçlı Türkçe öğrenmek isteyenlerin \% 54.11'i (Cramer's $V=.22$ ), iş amaçlı Türkçe öğrenmek isteyenlerin \% 50.79'u (Cramer's $V=.12$ ) ilgi göstermektedir. Akademik amaçlı öğrenmek isteyenlerin \% 71.10'u dil ve kültür alanına (Cramer's $V=.16$ ), \% 33.31'i edebiyat alanına (Cramer's $V=.13$ ) diğerlerine oranla daha çok ilgi göstermektedir.

Yabancı dil olarak Türkçe öğrenenlerin ilgi alanları çalışma durumu bağlamında incelendiğinde anlamlı bir farklılık olduğu görülmüştür $(\chi 2(14)=778.063, p<.001)$. Çalışanların \% 76.35'i, çalışmayanların \% 57.93'ü iş alanına (Cramer's $V=.33$ ) ilgili oldukları görülmektedir. Çalışma durumunu öğrenci olarak belirtenlerin \% 50.17'si bilim ve teknoloji (Cramer's $V=.07$ ) ile \% 72.42'si dil ve kültür (Cramer's $V=.13$ ) alanına çalışma durumunu çalışıyorum ve çalışmıyorum olarak belirtenlere oranla daha fazla ilgi göstermektedirler. Dünyadaki gelişmelere ilgi duyanlar incelendiğinde (Cramer's $V=.08$ ) bu alana en düşük ilgi oranının \% 37.11 ile öğrencilerde olduğu görülmektedir. Eğlence ve yaşam (Cramer's $V=.05$ ) alanı incelendiğinde ise ilgi oranının öğrenciler (\% 41.26) ve çalışmayanlarda (\% 43.32) çalışanlara (\% 38.39) kıyasla az bir farkla daha yüksek olduğu belirlenmiştir.

\section{Sonuç ve Tartışma}

Yabancı dil olarak Türkçe öğretimi yaklaşık olarak on beş yıllık bir geçmişe sahip olan yeni bir alandır (Biçer, 2017; Güzel, 2003). Bu bağlamda yeni ortaya çıkan her alan gibi çalışılması gereken pek çok konuyu barındırmaktadır. Yıldız ve Tuncel (2014), Türkçenin yabancı dil olarak öğretiminde ortaya çıkan sorunları (a) Yabancılara Türkçe öğretimine ait bir program eksikliği, (b) Hem öğretim yöntemi ve materyal hem de bunları geliştirmeye dair yöntem eksikliği, (c) Ölçme ve değerlendirmeye dair hem araç hem de araç geliştirme bağlamında yaşanan sorunlar olmak üzere üç başlık altında incelemektedir. Yabancılara Türkçe öğretimine ait standartları oturmuş bir programın olmayışı çalışmanın temel vurgularındandır. Öğretim yöntemi ile ilgili sorunların başında da neyin (alan bilgisi) nasıl öğretileceği konusunda henüz yeterli standardın gelişmemesi yer almaktadır. $\mathrm{Bu}$ bağlamda yapılması gerekenlerin başında hedef kitle analizinin geldiği belirtilmekte, hedef kitleye yönelik program geliştirme ihtiyacı vurgulanmaktadır. Öte yandan alanyazın ve alanyazındaki çalışmaların içerik analizleri (Aktaş ve Uzuner Yurt, 2015; Biçer, 2017; Büyükikiz, 2014; Dönmez ve Gündoğdu, 2016; Erdem ve diğ., 2015) incelendiğinde hedef kitle analizi için kapsamlı bir çalışma bulunmadığı görülmüştür. Bu bağlamda bu araştırma kitlesel açık çevrimiçi dersler üzerinden Türkçe öğrenmek isteyen bilgi ve iletişim teknolojilerine erişimde sorun yaşamayan yetişkinlere ait profil analizi ile alana katkı sağlamaktadır.

Araştırma sonuçlarına göre Türkçe Öğreniyorum sisteminde yabancı dil olarak Türkçe öğrenim taleplerinin çoğu Arap yarımadası kökenlidir. Türkçe öğrenmek isteyenlerin çoğunluğu erkeklerden oluşmaktadır. Yabancı dil olarak Türkçe öğrenmek isteyen her 3 kişiden 1'i kadın, 2'si erkektir. Yarısından fazlası 35 yaş altıdır. Yaş verisi, Yunus Emre Enstitüsü'nün (2016) verileri ile benzerlik göstermektedir. 2016 yılında Yunus Emre Enstitüsüne kayıtlanan 12000 kursiyerin \% 30’u 17-25 yaş aralığında \% 55’i 26-40 yaş aralığındadır. Bu bağlamda daha çok gençlerin Türkçe öğrenme eğiliminde olduğunu söylenebilir.

Türkçe Öğreniyorum sisteminde yabancı dil olarak Türkçe öğrenmek isteyenlerden \% 44.42'si tercih nedenleri arasında işi listelemektedir. Akademik amaçlar için Türkçe ihtiyacı öğrenenlerin \% 54.28'si tarafından belirtilmiştir. Türkiye'de yaşadığını belirten yabancıların akademik ve iş gereği Türkçe öğrenme oranı daha yüksekken, Türkiye dışında yaşadığını belirten yabancılar daha yüksek oranda genel amaçlı öğrenmeyi tercih etmektedirler. Akademik gerekçelerle ve iş için Türkçe öğrenme alanyazındaki diğer çalışmalarda da ilk sıralarda listelenmektedir (Başar ve Akbulut, 2016; Boylu ve Çangal, 2014; Çalışkan ve Çangal, 2013; Koçer, 2013; Maden ve İşcan, 2013; Tok ve Yıgın, 2013). Bu bağlamda öğretim içeriklerinin ihtiyaç alanlarındaki dil becerilerini geliştirici yönde özelleştirilmesi gerektiği ve Akademik Türkçe, Ticaret ve İş Türkçesi, Turizm Türkçesi gibi özel alan dillerine olan ihtiyacın yakın gelecekte daha belirgin hissedileceği söylenebilir.

Türkçe öğrenmek isteyenlerin yarıdan fazlası (\% 66.49) Türkiye'de yaşamaktadır. Diğer bir ifade ile yabancı dil olarak Türkçe öğrenimine şu anki durum itibarı ile yurtiçinden daha fazla talep olduğu söylenebilir. Yabancı dil olarak Türkçe öğrenenlerin \% 60.70’inin başka bir yabancı dil deneyimi yoktur. Türkiye'de yaşayanların eğitim seviyeleri ilköğretim/ortaöğretim ve lise ya da dengi okul seviyesinde, yurtdışındakilerin ise önlisans / lisans ve lisansüstü seviyesinde yoğunlaştı̆̆ görülmüştür. 
Yabancı dil olarak Türkçe öğrenmek isteyenlerin yarıya yakını (\% 44.27) çalışmaktadır. Yaklaşık olarak üçte biri (\% 28.53) öğrencidir. Bu bağlamda öğreneni işinden veya okulundan alıkoymamak adına yabancı dil olarak Türkçe eğitiminde uzaktan sistemlere ihtiyacın artacağını söylemek mümkündür. Yabancılara Türkçe öğretimi alanyazınındaki çalışmalar ağırlıklı olarak yükseköğretim seviyesindeki (ya TÖMER ya da yurtdışındaki Türkçe kurslarında) yetişkinlerle yürütülmüştür (İBGİGM, 2018).

Yabancı dil olarak Türkçe öğrenmek isteyenlerin \% 73.82'nin çevrimiçi ders deneyimi bulunmamaktadır. Çevrimiçi ders deneyimi, eğitim düzeyi yükseldikçe artmaktadır. Çevrimiçi ders deneyimi olmayanların çoğunluğu ilköğretim/ortaöğretim ve lise ya da dengi okul eğitim düzeyine sahip olanlar yönündedir. Çevrimiçi ders deneyimi önlisans / lisans ve lisansüstü eğitim düzeyi yönünde artmaktadır. Yurtdışında yaşadığını belirten yabancıların Türkiye'de yaşadığını belirtenlere oranla çevrimiçi ders almış olma durumu daha yüksektir. Bunun yanı sıra yabancı dil olarak Türkçe öğrenmek isteyenlerin sosyal ă̆ (\% 68.00) ve genel amaçlı internet kullanma (\% 64.01) oranları yüksektir. Erkekler bankacılık işlemleri ve web gelişme için kadınlara oranla daha yüksek kullanıma sahipken, kadınlar interneti erkeklere göre daha yüksek oranla ödev/araştırma yapmada tercih etmektedir. Ödev/araştırma ve bankacılık işlemlerini lisans ve lisansüstü eğitimi seviyesine sahip bireyler daha yüksek oranda gerçekleştirmektedir. Diğer bir anlatımla öğrenenler arasında eğitim düzeyi arttıkça bilinçli internet kullanım oranlarının arttığı söylenebilir. Bu bağlamda bilgi ve iletişim teknolojilerinin, özellikle mobil öğrenmenin, sürece dahil edilmesi hedef kitleye erişimi ve eğitimde fırsat ve imkân eşitliğini arttırabilir. Hedef kitlenin büyük oranda buna hazır olduğu görülmektedir. Ancak, alanyazındaki çalışmalar incelendiğinde Türkçe öğretiminde materyal olarak ders kitaplarına yönelim olduğu, ders kitapları ile ilgili çalışmaların sıklıkla yapıldığı göze çarpmaktadır (Aktaş ve Uzuner Yurt, 2015; Biçer, 2017; Bozkurt ve Uzun, 2015; Büyükikiz, 2014; Dönmez ve Gündoğdu, 2016; Erdem ve diğ., 2015). Bu durum formal eğitime dahil olmuş sınırlı bir kitleye erişim imkânı sağlamaktadır. Yabancı dil olarak Türkçe öğretim süreçlerinde artan talebi karşılamada imkanların yetersizliği özellikle mobil teknolojilerin işe koşulmasına yönelik ihtiyacı göstermektedir.

Yabancı dil olarak Türkçe öğrenenlerin ilgi alanları demografik bilgiler bağlamında incelendiğinde gruplar arasında anlamlı farklılıkların olduğu görülmüştür. Örneğin erkeklerin iş, dünyadaki gelişmeler, bilim ve teknoloji ve spor alanlarına kadınlara oranla daha çok ilgi gösterdikleri, bunun yanında kadınların ise eğlence ve yaşam, dil ve kültür ve edebiyat alanlarına erkeklere oranla daha ilgili oldukları görülmüştür. Türkiye'de yaşadığını belirten yabancıların iş ile Türkiye dışında yaşadığını belirten yabancıların ise dünyadaki gelişmeler, eğlence ve yaşam ve dil ve kültür alanları ile daha çok ilgilendikleri ortaya çıkmıştır. Çalışma durumunu öğrenci olarak belirtenler bilim ve teknoloji ile dil ve kültür alanına çalışma durumunu çalışıyorum, çalışmıyorum şeklinde belirtenlere oranla daha fazla ilgi göstermektedirler.

Açık ve uzaktan öğrenme alanında profil analizi bağlamında önceki e-öğrenme deneyimi, yaş, cinsiyet, eğitim seviyesi, öğrenme stili, amaçları ve tercihleri, önceki bilgi düzeyi sıklıkla irdelenmiştir (Burton-Jones ve Hubona, 2006; Ford ve Chen, 2000; Garland ve Martin, 2005; Liu, Liu, Lee ve Magjuka 2010; Venkatesh, Morris ve Ackerman, 2000). Bu çalışmaların temel hedefi öğrenmenin daha anlamlı, etkili ve verimli hale getirilebilmesi için öğreneni tanıma, öğrenen ilgi, ihtiyaç ve eğilimlerini tespit etmektir. Günümüzde uzaktan eğitim platformları bireylerin ilgi alanları, yetenek ve becerilerine göre eğitim süreçlerini bireyselleştirme yeteneğine sahip hale gelmiştir. Yabancılara Türkçe öğretiminde de bireylerin; kendi yetenek ve özelliklerine uygun eğitim öğretimden faydalanmaları için hedef kitle analizi çalışmalarının artması ve makine öğrenmesi süreçlerinin işe koşularak alanda yordayıcı istatistiki bilgilerin oluşturulmasına ihtiyaç vardır. Bu bağlamda araştırmanın ilerleyen aşamalarında, bu çalışmada elde edilen de bulgular temel alınarak öğrenenlerin başarı düzeyleri, devam ve bırakma oranları, sistemdeki gezinim hareketleri, motivasyonları, öz-düzenleme becerileri, en çok hata yaptıkları, en çok tekrar ettikleri konular, en hızlı ilerledikleri konular gibi alt boyutlar araştırılarak alana katkı sağlanabilir. Son yıllarda Türkiye Türkçesini öğrenmeye farklı coğrafyalardan talep vardır. Bunda Başbakanlık tarafından kurulan Yunus Emre Enstitüsü ve Yurtdışı Türkler Başkanlığı'nın faaliyetleri etkili olmuştur (Başar ve Akbulut, 2016; Yunus Emre Enstitüsü, 2016). Bu iki kurum Türkiye'nin ekonomik, sosyal ve siyasi alanlarda dünyayla rekabet edebilme hedefi bağlamında tüm dünyada Türkiye'nin tanıtımı ve Türkçenin yaygınlaştırılmasını kendisine misyon edinmiştir (Yunus Emre Enstitüsü, 2019; Yurtdışı Türkler Başkanlığı, 2019). Dünya geneline bakıldığında farklı ülkelerin benzer kuruluşlarını görmek mümkündür. Fransızların Alliance Française kurumu, İngilizlerin British Council yapısı, İspanyolların Cervantes Enstitüsü, Almanların Goethe Enstitüsü, İtalyanların Istituto Italiano di Cultura kuruluşu ve Avusturyalıların Österreich Enstitüsü bunlara örnek verilebilir. Söz konusu kuruluşlar uzun yıllardır aynı tarzda etkinlikleri başarılı bir şekilde yürütmektedirler. Türkiye'nin bu alandaki çalışmaları yeni olduğundan -yaklaşık on beş yıllık bir geçmişi bulunmaktadır- Türkçenin yüz yüze öğretiminde diğer global dillerle rekabet edebilmesi ve yaygınlaştırması yetersizdir (Biçer, 2017; Güzel, 2003; İşcan, 2011). Türkçeyi dünya genelinde öğretmek isteyen resmî ve özel kurumlar yüz yüze eğitimle istenen sayıda geniş kitleye ulaşamamaktadır. Türkçenin yabancılara uzaktan öğretimi bu eksiği kapatmak ve kişiye özel, esnek, zamandan ve mekândan bağımsız bir öğretim içeriği sunabilmesi yönüyle avantaj sağlayabilir. 


\section{Kaynakça/References}

Aktaş, E. ve Uzuner Yurt, S. (2015). Türkçe eğitimi alanındaki makale özetlerine yönelik bir içerik analizi. Turkish Studies, 10(7), 73-96. doi:10.7827/TurkishStudies.8121

Başar, U. ve Akbulut, E. (2016). Yabancılara Türkçe öğretiminde öğrenen ihtiyaçlarının belirlenmesi: Yunus Emre Enstitüsü Tiflis Türk Kültür Merkezi Örneği. Uluslararası Türkçe Edebiyat Kültür Eğitim Dergisi, 5(2), 1005-1020.

Biçer, N. (2017). Yabancılara Türkçe öğretimi alanında yayınlanan makaleler üzerine bir analiz çalışması. Pamukkale Üniversitesi Sosyal Bilimler Dergisi, 27(Mayıs), 236-247. doi:10.5505/pausbed.2017.69772

Boylu, E. ve Çangal, Ö. (2014). Yabancılara Türkçe öğretiminde dil ihtiyaç analizi: İran örneği. International Journal of Language Academy, 2(4), 127-151.

Bozkurt, B. Ü. ve Uzun, N. E. (2015). Türkçenin eğitimi-öğretimine ilişkin bir alanyazını değerlendirmesi: Uluslararası bilimsel toplantılarda eğilimler/yönelimler. Dil Eğitimi ve Araştırmaları Dergisi, 1(2), 1-15.

Burton-Jones, A., \& Hubona, G. S. (2006). The mediation of external variables in the technology acceptance model. Information \& Management, 43(6), 706-717.

Büyükikiz, K. K. (2014). Yabancılara Türkçe öğretimi alanında hazırlanan lisansüstü tezler üzerine bir inceleme. Mustafa Kemal Üniversitesi Sosyal Bilimler Enstitüsü Dergisi, 11(25), 203-213.

Class Central, (2017). Massive list of MOOC providers around the world. https://www.classcentral.com/report/mooc-providers-list/ adresinden elde edildi.

Çalışkan, N. ve Çangal, Ö. (2013). Yabancılara Türkçe öğretiminde dil ihtiyaç analizi: Bosna-Hersek örneği. Abant İzzet Baysal Üniversitesi Ĕ̌itim Fakültesi Dergisi, 12(2), 310-334.

Dönmez, B. ve Gündoğdu, K. (2016). 2000-2016 yılları arasında Türkçe öğretim programları alanında yayımlanan makale ve tezlerin analizi. Uluslararası Türkçe Edebiyat Kültür Eğitim Dergisi, 5(4), 21092125.

Erdem, M. D., Gün, M., Şengül, M. ve Özkan, E. (2015). Yabancı dil olarak Türkçe öğretimi alanında yazılmış bilimsel makalelerde geçen anahtar sözcüklere ilişkin bir içerik analizi. Ondokuz Mayıs üniversitesi Eğitim Fakültesi Dergisi, 34(1), 213-237. doi:10.7822/omuefd.34.1.13

Ford, N., \& Chen, S. Y. (2000). Individual differences, hypermedia navigation, and learning: an empirical study. Journal of Educational Multimedia and Hypermedia, 9(4), 281-311.

Garland, D., \& Martin, B. N. (2005). Do gender and learning style play a role in how online courses should be designed. Journal of Interactive Online Learning, 4(2), 67-81.

Güzel, A. (2003). Türkçenin eğitimi-öğretimi bölümlerinde kurulması gerekli görülen anabilim dalları hakkında yeni projelerimiz. Türkiyat Araştırmaları Dergisi, 13(2003), 13-86.

İBGİGM: İçişleri Bakanlığı Göç İdaresi Genel Müdürlüğü (2016). Göç Raporu. http://www.goc.gov.tr/files/files/2016_goc_raporu_.pdf adresinden elde edildi.

İBGİGM: İçişleri Bakanlığı Göç İdaresi Genel Müdürlüğü (2018). Yıllara göre ikamet izni ile ülkemizde bulunana yabancllar. http://www.goc.gov.tr/icerik6/ikamet-izinleri_363_378_4709_icerik adresinden elde edildi.

İşcan, A. (2011). Türkçenin yabancı dil olarak önemi. Uluslararası Avrasya Sosyal Bilimler Dergisi, 2(4), 29-36.

Kirkwood, A., \& Price, L. (2011). Enhancing Learning and Teaching Through Technology: A Guide to Evidence-Based Practice for Policy Makers. York, UK: Higher Education Academy.

Koçer, Ö. (2013). Program geliştirmenin ilk basamağı: Yabancı dil olarak Türkçe öğretiminde ihtiyaç ve durum analizi. Eğitim ve Bilim Dergisi, 38(169), 159-174. 
Liu, X., Liu, S., Lee, S.-H., \& Magjuka, R. J. (2010). Cultural Differences in Online Learning: International Student Perceptions. Educational Technology \& Society, 13(3), 177-188.

Liu, M., Moore, Z., Graham, L., \& Lee, S. (2002). A look at the research on computer-based technology use in second language learning: A review of the literature from 1990-2000. Journal of Research on Technology in Education, 34(3), 250-273.

Maden, S. ve İşcan, A. (2015). Yabancı dil olarak Türkçe öğretimi amaç ve sorunlar (Hindistan Örneği). Karadeniz Sosyal Bilimler Dergisi, 3(5), 23-38.

May, S., \& Thorne, S. (2017). Encyclopedia of language and education: Language and technology. Switzerland: Springer.

Moore, M. G., \& Kearsley, G. (2005). Distance education: A systems view. Belmont, CA Thomson Wadsworth.

Nicoll P, MacRury S, van Woerden HC, Smyth K (2018) Evaluation of technology-enhanced learning programs forhealth care professionals: Systematic review. Journal of Medical Internet Research, 20(4). doi:10.2196/jmir.9085.

Ozan, Ö. ve Göçmenler, H. (2018). Türkçenin yabancı dil olarak uzaktan farklılaştırılmış öğretimi projesi. Uludă̆ Üniversitesi Eğitim Fakültesi Dergisi, 31(Özel sayı), 129-134. doi:10.19171/uefad.430162

Ozan, O., Ozarslan, Y., \& Yildiz, H. S. (2018). MOOLC design and development process for an agglutinative language: Türkçe Öğreniyorum case. The Turkish Online Journal of Educational Technology, 2(Special Issue), 156-164.

Ozarslan Y., \& Ozan, O. (2017). Massive open online course (MOOC) for differentiated instruction of Turkish as a foreign language. Proceedings of Society for Information Technology \& Teacher Education International Conference 2017, 1(1), 266-272.

Özdemir, E. (2014). Tarama Yöntemi. İçinde M. Metin (Ed.), Kuramdan uygulamaya ĕgitimde bilimsel araştırma yöntemleri (s. 77-97). Ankara: Pegem Akademi Yayıncılık.

Özsoy, S. ve Özsoy, G. (2013). Eğitim araştırmalarında etki büyüklüğü raporlanması. İlköğretim Online, 12(2), 334-346.

Perifanou, M. (2015). Personalized MOOCs for language learning: A challenging proposal. ELearning Papers, 45(1).

Perifanou, M. (2016). Worldwide state of language MOOCs. In S. Papadima-Sophocleous, L. Bradley \& S. Thouësny (Eds), CALL communities and culture - short papers from EUROCALL 2016 (pp. 386-390). doi:10.14705/rpnet.2016.eurocall2016.593

Tok, M. ve Yııın, M. (2013). Yabancı uyruklu öğrencilerin Türkçe öğrenme nedenlerine ilişkin bir durum çalışması. Dil ve Edebiyat Ĕ̆itimi Dergisi, 8, 132-147.

Venkatesh, V., Morris, M. G., \& Ackerman, P. L. (2000). A longitudinal field investigation of gender differences in individual technology adoption decision-making processes. Organizational Behavior and Human Decision Processes, 83(1), 33-60.

Yıldız, Ü. ve Tunçel, H. (2014). Yabancı dil olarak Türkçe öğretiminde karşılaşılan sorunlar ve öneriler. İçinde A. Şahin (Ed.), Yabancı dil olarak Türkçe öğretimi: Kuramlar, yaklaşımlar, etkinlikler (s. 175-206). Ankara: Pegem.

Yunus Emre Enstitüsü (2009). Yunus Emre Bülteni. http://www.yee.org.tr/media/_bulten/pdf/eylul_2009.pdf adresinden elde edildi.

Yunus Emre Enstitüsü (2016). YEE $2016 \quad$ Faaliyet Raporu. https://www.yee.org.tr/sites/default/files/yayin/2016_faaliyet_raporu_05.02.2018-db.pdf adresinden elde edildi.

Yunus Emre Enstitüsü (2019). https://www.yee.org.tr/tr/kurumsal/yunus-emre-enstitusu adresinden elde edildi. 
Yurtdışı Türkler Başkanlığı (2019). https://www.ytb.gov.tr/ adresinden elde edildi.

Yükseköğretim Kurulu Başkanlığı (2018). Yükseköğretim bilgi yönetim sistemi öğrenci verileri. https://istatistik.yok.gov.tr/ adresinden elde edildi. 